\title{
Real Problems, Real Research, Real Students: Authentic Research with Undergraduates as a Win-Win-Win Collaboration
}

\author{
Carl-Georg (Charly) Bank \\ University of Toronto \\ Anne Marie Ryan \\ Dalhousie University
}

Authentic research, in which students pose original questions and attempt to find the unknown answers, addresses principles of undergraduate education in an ideal way. With careful planning and reasoned considerations it will benefit students, faculty, and institutions.

\section{Introduction}

66 Tndergraduate research is defined broadly to include scientific inquiry, creative activity, and scholarship.... The key is that the project produces some original work" (Kinkead, 2003). It is generally accepted that engaging students in undergraduate research provides them with an enriched and positive learning experience (Boyer, 1998; Laursen et al., 2006). In field- and laboratory-based activities - traditionally an important component of undergraduate education, especially in the sciences (Holt, Abramhoff, Wilcox, \& Abell, 1969) - students are often asked to re-create data and tackle questions with a predetermined solution. In contrast, undergradu- ate research is based on original questions with open answers. Such authentic research requires that all involved have some say in the direction of the research and develop self-efficacy through shared communication (Desai et al., 2008). Authentic research experiences on a variety of scales and over varying lengths of time thus provide avenues for students to create new knowledge and understanding, even at the early stages in their university careers. In such inquiry-based activities students learn by doing research (see Jenkins, Healey, \& Zeiter, 2007). In the following, we summarize benefits, discuss considerations, and examine a number of models from our own work. 


\section{Benefits of Undergraduate Research}

Engaging undergraduate students in authentic research benefits students, their faculty supervisors, and their institutions. Many students can excel in the excitement of research. Research enables them to develop critical and divergent thinking skills and obtain a sense of ownership of the learning process. Their varied backgrounds and interests to discipline-specific research transcend cultures, and by sharing in the progression towards the mastery of a subject, they build a sense of community and understanding with fellow students and faculty. Faculty can discover the fun in teaching as they share ideas about topics of particular interest to them. Indeed, engaging in undergraduate research allows faculty to interconnect their teaching and research in novel ways (Sabatini, 1997). Many institutions, especially large research universities, build their reputation on research. By investing early in undergraduate research they can become stronger because of better student retention and improved student engagement (Kinkead, 2003). Overall, undergraduate research can address and encompass Seven Principles for Good Practice in Undergraduate Education (Chickering \& Gamson, 1987), as outlined in Table 1.

Undergraduate research has therefore the potential to address the principles; although, a faculty member willing to offer such experience to his or her students needs to think about each principle to make the experience most effective. With appropriate planning and consideration, undergraduate research becomes an ideal venue for teaching undergraduates.

\section{Considerations}

Engaging undergraduate students in research requires planning and thought. This section features possible pitfalls, anxieties, or obstacles the different parties in the learning process may face, and suggests possible solutions.

\section{Table 1}

\section{Seven Principles for Good Practice in Undergraduate Education}

\begin{tabular}{|l|l|}
\hline Principle for good practice & Role of undergraduate research in facilitating good practice \\
\hline $\begin{array}{l}\text { Encourages contact between } \\
\text { students and faculty }\end{array}$ & $\begin{array}{l}\text { Students interact frequently with faculty individually, or in } \\
\text { small group settings. }\end{array}$ \\
$\begin{array}{l}\text { Develops reciprocity and } \\
\text { cooperation among students }\end{array}$ & $\begin{array}{l}\text { The research requires collaboration with peers, from sharing } \\
\text { equipment and/or data, to exchanging ideas. }\end{array}$ \\
\hline Uses active learning techniques & $\begin{array}{l}\text { Authentic research, by definition, engages students in active } \\
\text { learning. }\end{array}$ \\
Gives prompt feedback & $\begin{array}{l}\text { Prompt feedback is intrinsic to the research experience } \\
\text { (each step in the research process informs the next step), in } \\
\text { addition to ongoing feedback from peers and faculty. }\end{array}$ \\
\hdashline Emphasizes time on task & $\begin{array}{l}\text { Research is time-limited (constrained by course) and goal- } \\
\text { oriented, and demands good time management. }\end{array}$ \\
\hdashline $\begin{array}{l}\text { Communicates high } \\
\text { expectations }\end{array}$ & $\begin{array}{l}\text { Research requires a high level of commitment to succeed: } \\
\text { faculty set this expectation from the start. }\end{array}$ \\
\hdashline $\begin{array}{l}\text { Respects diverse talents and } \\
\text { ways of learning }\end{array}$ & $\begin{array}{l}\text { Collaborative research involves drawing on the diverse } \\
\text { talents of individuals, and succeeds best when mutual } \\
\text { respect is the expected norm. }\end{array}$ \\
\hline
\end{tabular}




\section{The student perspective}

Authentic research is quite distinct from our students' usual university experience. As teachers, we typically train them to provide the predetermined answer to a question we pose, but research requires us to ask questions for which no one knows the answer (e.g., Schwartz, 2008). This can be frustrating to students. In addition, students wishing to experience research first-hand may not feel adequately prepared, and often lack the necessary background, although they may not be aware of this. Having never done research, they cannot acknowledge nor do not expect that the research process to be messy and unpredictable, and that often, much time must be devoted to marginal problems (e.g., equipment malfunction). Students must have realistic time commitments, be motivated to enter a research obligation, and know where to find resources and who to solicit for help. Sometimes they may find themselves with other students who have different objectives and they may struggle to work through these differences. Even when they get through all these pitfalls, they may become frustrated if their results end up in a drawer without being shared.

The undergraduate research experience will be enhanced if faculty members and their institutions consider integrating skills (writing, information literacy, numeracy) into the curriculum and introduce or amend early courses to incorporate inquiry and research methodology. In other words, consideration of the development of the student as a novice researcher must be addressed in the planning. It may be advisable to ask for prerequisite courses and/or a minimum entrance grade, although Kinkead (2003) discusses the benefits for all students. Student involvement in a research project should be transparent, and there should be a "reward" system in place: either they are hired as student assistants with pay, or they earn credit towards their degree. Supervisors should debrief them about the process, and mentor them throughout the duration of their involvement (Kinkead, 2003). Faculty should also encourage and support their students to communicate and receive feedback on their work, for example via a presentation in a departmental seminar. Some universities hold poster days or symposia dedicated to research within the university community, and faculty should also consider regional or local conferences that encourage undergraduate research contributions, either within their own disciplines or across faculty interests. There are also peer-reviewed publications dedicated to undergraduate research findings (Council on Undergraduate Research, 2008).

\section{The faculty perspective}

Supervising undergraduate student research requires time, resources, and interpersonal skills. Preparation of a project involves work and commitment, yet results may be less reliable, the number of places for students is limited, and student attitudes are unpredictable. Research is expensive if it needs equipment, consumables, and travel. Initial stages of a project require time, especially if permissions and an ethics review are required. The possibility that the effort may not lead to a publication will make research faculty, especially if they are untenured, hesitant to add such responsibility to their workload; the lack of resources and recognition may dampen the enthusiasm of teaching faculty.

Faculty need to set up a suitable - realistic but demanding - project and may rely on their research group comprised of advanced undergraduate and possibly graduate students for ongoing support of their novice learners. Issues of responsibility must be communicated at the start for all involved. To facilitate the training about techniques and procedures, novice learners can be paired with advanced students. Trial runs may be useful for faculty and students to decide if students are suited, interested, and capable for this research. To ensure accountability, studies can be run more than once. Faculty members should showcase the results of undergraduate research by encouraging oral and poster presentations. Professors should tap funding sources from their institution and community, and could include support for undergraduate involvement into their research proposals. In the United States, projects targeted as Research Experience for Undergraduates can apply for federal support (National Science Foundation, 2008); unfortunately, federal agencies in Canada do not share a similar mandate. Most importantly, faculty must see such efforts as a legitimate and necessary goal of their work, rather 
than a burden or distraction from their research; indeed, integrating teaching and research may serve to greatly enhance the research in the long term.

\section{Institutional perspective}

Institutions stand to gain a lot in terms of student retention and prestige, yet may be hesitant to support undergraduate research due to lack of resources both financially and administratively, and because of concerns about funneling scarce funds into small groups of students. Equity issues may also play a role; in particular, which students can benefit, and which disciplines shall participate?

Funding is a key element for successful research, and institutions can help attract funding by publicizing research results from their undergraduates and explaining the benefits to potential donors and granting agencies. Institutions may encourage research grants to include an undergraduate component. They can provide administrative support to departments and faculty by setting up a mentorship program. They should take measures to cover risks, especially those involved with fieldwork. Institutions need to reward faculty offering undergraduate research, for example, by counting such work as part of their workload. Institutions should also discuss a shift of expectations: the goal of undergraduate research is not only to produce research, but also to educate and develop future researchers.

\section{Examples of Undergraduate Research Projects}

Undergraduate research can take many forms, and may require very different time scales to complete. Whereas the following models draw mostly from our backgrounds in science, the possibilities of applying them in other disciplines abound, and they do not serve as prescriptions for possible activities.

\section{Research activity within a course}

Many science classes offer a lab component to improve the understanding of concepts learned in lectures. For example, students in an introductory geo- physics course are asked to model data on a computer. In this particular course, students were required during a two-hour exercise to measure gravity over an area on campus known to have underground labs. Just after this lab, one student noted:

The best part about the gravity lab is that it is more creative than most of the other labs we do in school, where we just follow a recipe on a sheet. Beyond learning how to use new equipment, the lab lets us learn to deal with a real situation, where there is no pre-determined way to go about things. I think that being given the opportunity to think about how to run a survey ourselves is the most valuable part of the course, since those skills are transferable to other situations.

Later, students analyzed their data and wrote a short report. Thus, the experience became an integrated exercise, which provided students with the opportunity to learn first-hand about the effort that goes into setting up the experiment, obtaining a useful dataset, and presenting their results in a meaningful way. The data set these students have acquired can plant the seed for a more in-depth study of gravity anomalies on campus.

Another example of course work includes both individual and group research components. A pre-existing, unprocessed data set from approximately 30 lakes in a growing urban-suburban-rural region collected over the past three decades provided a longitudinal study of changes in lake chemistry. Small groups of a second-year geochemistry class were given sub-sets of these data with the main intent of developing their skills in working with geochemical data, graphing, and basic interpretation. However, as work on the assignment progressed, other objectives unfolded. Students determined trends within the data, and attempted to account for these based on where the lakes were situated. Another objective (that students will pursue in the future) is to combine these different sub-data sets into a map base, and establish overall trends and contamination 'hot spots' in relation to urban, forest, mining, and agricultural devel- 
opment through the 30-year window. Together these objectives would allow the students to gain skill in processing databases, develop an understanding of the need for scientists to communicate and share results, and further develop teamwork and responsibility to the research process. Integrating principles of research using real, raw data in a class-wide activity provides a logical starting point for undergraduate research. Indeed, data from Statistics Canada could be similarly addressed in the humanities and business fields, as students collectively 'create new knowledge.'

\section{Research-specific course}

Institutions and departments may consider offering specific courses which are centered on a research project. Students may generate the research question themselves, and faculty facilitate students' successful completion of the project, or the course may link to a faculty member's own research. Both approaches provide students with opportunities to experience the process of doing science.

The first approach was taken in a course on research methods. Students had to come up with their individual projects, develop a testable hypothesis, obtain data, analyze it, and at the end of the course, present posters of their findings to the department. Student evaluations were very positive; one student who was planning on becoming a high-school teacher wrote: "I wish that more courses focused solely on student motivated activities...where the student is empowered to learn, not forced to do activities."

Specific research courses are offered by some institutions for undergraduates in their second and third years of study. Students can apply to a wide range of projects, faculty supervise them over several months and submit a grade, and the institution provides financial and administrative support (e.g., Faculty of Arts and Science, 2008). In this approach, the student experience is usually embedded into a faculty member's research interests and may provide a way for teaching faculty to remain active in research.

\section{Honours theses projects}

This may be the most common form of authentic undergraduate research. At this stage in their undergraduate program, students can synthesize what they have learned in several years of undergraduate studies. Often the thesis project spans the entire year, starting with data collection in the summer and culminating in a presentation at the end of the academic year. Key to the success of the honours research is mentoring, typically by a faculty member who supervises the thesis, but this also may be undertaken in part by a graduate student or postdoctoral fellow who thus develop their skills at mentoring and communication. Many departments have some sort of formal presentation process. Unfortunately, just few undergraduate students get to present their work at a national or international meeting; those that do usually have a very positive experience. The following quote from a student involved in a one-year, multi-institutional project exemplifies the variety of skills an undergraduate acquires in authentic research:

I learned many things about myself, teamwork and geophysics...First, I improved focus skills needed to see a project through its completion. [Second] I improved my interpersonal skills... [Third] I learned how to absorb a lot of material within a short amount of time...Lastly, I...had to improvise and innovate and create solutions to problems that are not encountered in lab experiments.

\section{Concluding Remarks}

Undergraduate research, if considerate of students' needs, supportive of faculty's commitment, and placed within the context of an institution's teaching mandate, has the potential of becoming one of the most beneficial and enriching undergraduate experiences. We have outlined in this article what faculty and institutions need to consider when offering undergraduate research. Any discipline can offer authentic research experiences to their students, although projects will be very different and may not include a field component. We have presented mod- 
els from our work in the earth sciences. The Higher Education Academy (2008) showcases examples of how teaching and research can be meshed for other disciplines. When approached thoughtfully, authentic research will create a win-win-win situation because it will benefit undergraduate students, supervising faculty, and institutions.

\section{Acknowledgements}

We thank all participants at our STLHE session "Real problems, real research, real students: possible models for authentic undergraduate research, with examples from the natural sciences." This paper expands on the discussion and insights from that session.

\section{References}

Boyer Commission on Educating Undergraduates in the Research University. (1998). Reinventing undergraduate education: A blueprint for America's research universities. State University of New York-Stony Brook.

Chickering, A.W., \& Gamson, Z.F. (1987). Seven principles for good practice in undergraduate education. AAHE Bulletin, 39(7), 3-7.

Council on Undergraduate Research. (2008). Undergraduate journals. Retrieved October 7, 2008, from http://www.cur.org/ugjournal.html

Desai, K.V., Gatson, S.N., Stiles, T.W., Stewart, R.H., Laine, G.A., \& Quick, C.M. (2008). Integrating research and education at researchextensive universities with research: intensive communities. Advances in Physiological Education. 32, 136-141.

Faculty of Arts and Science. (2008). Independent experiential study program. Retrieved October 7, 2008, from University of Toronto Website: http://www.artsci.utoronto.ca/current/ undergraduate/ies
Higher Education Academy. (2008). Research and teaching. Retrieved September 26, 2008, from http://www.heacademy.ac.uk/ourwork/ research/teaching

Holt, C.E., Abramhoff, P., Wilcox, L.V., \& Abell, D.L. (1969). Investigative laboratory programs in biology: A position paper of the commission on undergraduate education in the biological sciences. Bioscience, 19, 11041107.

Kinkead, J. (2003). Learning through inquiry: An overview of undergraduate research. New Directions for Teaching and Learning, 93, 5-17.

Laursen, S., Hunter, A.B., Seymour, E., DeAntoni, T., DeWelde, K., \& Thiry, H. (2006). Undergraduate research in science: Not just for scientists anymore. In J. J. Mintzes \& W. M. Leonard (Eds.), Handbook of college science teaching (pp. 55-66). Arlington, VA: NSTA Press.

Jenkins, A., Healey, M., \& Zetter, R. (2007). Linking teaching and research in disciplines and departments. York, UK: The Higher Education Academy.

National Science Foundation. (2008). Research experience for undergraduates. Retrieved September 25, 2008, from http://www. nsf.gov/funding/pgm_summ.jsp?pims_ id $=5517 \&$ org $=$ NSF.

Sabatini, D.A. (1997). Teaching and research synergism: The undergraduate research experience. Journal of Professional Issues in Engineering Education and Practice, 123, 98102.

Schwartz, M.A. (2008). The importance of stupidity in scientific research. Journal of Cell Science, 121, 1771. 


\section{Biographies}

Charly Bank is a Senior Lecturer at the University of Toronto, Ontario. He has encouraged undergraduates to participate in geophysical research projects that took them to remote areas in Canada and the United States and culminated in presentations at international conferences.

Anne Marie Ryan is a Senior Instructor at Dalhousie University in Nova Scotia. Her research interests centre on environmental geochemistry. She has supervised a number of honours students who have presented their work at local conferences, and worked at developing in-class authentic research activities for undergraduate students. 